\title{
Cross-cultural analysis of the ecological behavior of Chilean and Spanish ecotourists: a structural model
}

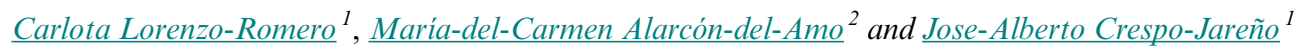

\begin{abstract}
Citizen concern for the environment in light of problems such as freshwater shortages, deforestation, and climate change has been steadily increasing in postmodern societies since the mid-20th century. Ecotourists and their proenvironmental or proecological behavior are still areas of opportunity for research in order to understand the factors, whether economic, cultural, social, demographic, or psychographic, that determine this behavior. This research uses the value-belief-norm (VBN) theory and the theory of planned behavior (TPB) to analyze the intention to practice ecotourism among ecotourists from two countries with different cultures and customs. Based on these premises, the objective of this work is to create a new model that facilitates the understanding of the intention to practice ecotourism, as well as the intention to pay more for it, by comparing ecotourists from two different cultures, Chilean and Spanish, in which the importance of ecotourism is similar. The data were obtained from a panel of 809 ecotourists (406 Chileans and 403 Spaniards) through partial least squares-structural equation modeling. The results indicate that the model is a good fit to the data; therefore, the hypotheses were confirmed. Specifically, the construct of conscience in consequences and the construct of personal norms have a strong influence on the intention to practice ecotourism. The results suggest that the proposed model is a useful framework for understanding the behavioral intention of ecotourists from different countries and their intention to pay more for ecotourism. The cultural differences between the two countries did not affect the causal relations established in the model in any way.
\end{abstract}

Key Words: causal relationships; Chile vs. Spain; cross-cultural studies; ecological behavior; ecotourism; PLS ${ }^{\circledR}$

\section{INTRODUCTION}

The interest in research on the ecological behavior of society in general and of individuals in particular has led scholars in different disciplines, including social psychology, sociology, and marketing, to produce many studies, some focusing on sociodemographic aspects and others focusing on aspects of social psychology (Liu et al. 2018). Concern for the environment among tourists in recent decades has led to the explosion of so-called sustainable tourism and ecotourism, which attempts to reconcile environmental values and tourism development (Dias 2007, Puhakka and Siikamäki 2012, Hwang and Lee 2018). According to Epler Wood (2002), ecotourism is an alternative tourism that practices nature tourism by helping to conserve the environment in which the tourist is received for the benefit of both visitors and the local destination community. Different authors have found that ecological behavior and the internal or external factors such as culture that determine such behavior can lead to new forms of tourism, such as ecotourism or nature tourism (Hultman et al. 2015, Hwang and Lee 2018).

To manage ecological behavior and understand the feedback between ecosystems and humans, Martone et al. (2017) develop a qualitative model to analyze complex social-ecological systems (SES), focusing on the observation of behavioral results in relation to external perturbation of ecosystems. Their model is congruent with the value-belief-norm (VBN) model (Stern et al. 1999), in which basic human values (Schwartz and Bilsky 1987), personal normative influence (PNI; Schwartz 1977), and the new environmental paradigm (NEP; Van Liere and Dunlap 1978) are analyzed to test the basic human values that guide the generation of attitudes in different international contexts. These socialecological behaviors differ depending on the ecosystems analyzed and are associated with different external and internal perturbations, such as culture, economic situation, and motivation. In sum, integrating ecological and psychologicalsocial variables into a unique unit of management reveals relevant potential trade-offs between desirable ecological and social outcomes. In this sense, it is important to note the user groups that might be vulnerable to external perturbations and identify the specific interventions that should be further tested to identify potential beneficial outcomes across the sustainable development paradigm (Martone et al. 2017). In this way, interest in conserving the natural environment can encourage consumers to consider the environment in their day-to-day activities (Untaru et al. 2014). This consideration translates into a growing preference for purchasing products that are less harmful to the natural environment (Laroche et al. 2001), thus reducing waste, using nontoxic substances, modifying consumption patterns, and conserving energy (do Paço et al. 2014, Chen 2015). In the tourism sector, the profile of tourists has changed, and they increasingly demand activities that do not harm the environment (PulidoFernández and López-Sánchez 2016). A consumer reaction against traditional or mass tourism, which denotes consumer habits and demand for sophisticated services based on activities such as visits to beaches, historic cities, or cultural attractions, has given rise to so-called alternative tourism. This type of tourism has emerged in the 21 st century as tourists have participated in activities that bring them into contact with nature; respect heritage, especially historical heritage; and enable them to interact with the local population. This emphasis has led to the emergence of different forms of tourism, such as cultural tourism, rural tourism, agrotourism, ecotourism, adventure tourism, and hunting (Ibáñez and Rodríguez 2012).

Concern for the environment has also changed the tourism industry and caused an upsurge in what have been termed sustainable tourism and ecotourism, which seek to combine environmental values and the development of tourism (Puhakka 
and Siikamäki 2012). This type of tourism is currently growing three times more rapidly than conventional tourism and aspires to a more prominent place in the global tourism market (Das and Chatterjee 2015).

The Sectoral Plan for Nature and Biodiversity Tourism 2014-2020 (https://www.miteco.gob.es/ca/biodiversidad/temas/conservacionde-la-biodiversidad/conservacion-de-la-biodiversidad-en-espana/ cb esp plan sect turismo nza y biodiversidad.aspx) proposes a model to follow in nature tourism and biodiversity: "A model that contributes to the value of natural wealth for ecotourism, that promotes balanced socio-economic development and drives the generation of income and employment, without undermining biodiversity and improving its management and conservation." Actions include promoting the configuration of sustainable destinations and tourism products and improving the consideration of biodiversity, as well as knowledge of it, in ecotourism activities. According to data from the World Tourism Organization (2019), ecotourism has grown significantly in recent decades, accounting for $15 \%$ of total world tourism. It is a growing activity in Spain (MAPAM 2017) and Chile (Senatur 2017). In sum, ecotourism is an economic resource for the development of local populations near the observed destinations and promotes knowledge of the natural environment and the species that inhabit it. Therefore, nature tourism has become an integrative tool for improving the economy of rural areas and bringing visitors closer to the work of protecting and conserving natural resources.

Research on consumer behavior aims to understand the attitudes of ecotourists (Han 2015, Hultman et al. 2015, Han et al. 2017, Kiatkawsin and Han 2017, Hwang and Lee 2018), characterizing ecotourism as "a particular type of alternative tourism closely associated with environmentally and culturally sensitive areas" (Lu et al. 2016:176). However, the ecological behavior of these consumers is a field of research that still has unexplored areas, especially regarding a better understanding of the importance of psychographic, personality, cultural, economic, and demographic factors (Weaver and Lawton 2002, do Paço and Raposo 2009, Han 2015, Hultman et al. 2015, Kiatkawsin and Han 2017). Typically, research on ecological behavior is carried out through the study of different forms of behavior, whether in the private sphere or the public sphere, e.g., social and political participation, energy saving, etc. (Stern 2000, Steg et al. 2005, Yeboah and Kaplowitz 2016). In the field of tourism, it is common to study behaviors such as visiting ecological hotels or natural parks (van Riper and Kyle 2014, López-Mosquera and Sánchez 2011). Similarly, some investigations are linked to behavior intention, which, according to Ajzen (1991), is the closest antecedent to the realization of a behavior, such as the intention to visit ecological museums (Han and Hyun 2017), the intention to visit an ecological hotel (Choi et al. 2015, Han 2015) or the intention to behave in an ecological way while traveling (Kiatkawsin and Han 2017, Landon et al. 2018).

Research on ecotourist behavior is based on the analysis of either consumption intention or consumption itself (Han 2015, Kiatkawsin and Han 2017). Our approach follows the theory of planned behavior (TPB; Ajzen 1991), which points out that the antecedent closest to a particular behavior indicates the individual's willingness to perform that behavior (de Groot and Steg 2008). In addition, the VBN model (Stern et al. 1999) has been shown to be a powerful framework for explaining different ecological behaviors (Stern 2000), such as citizens' movements, political actions, and political support (Yeboah and Kaplowitz 2016), and for understanding proecological behavior in the field of tourism (Han 2015, Choi et al. 2015, Han and Hyun 2017). We choose to study the intention to practice ecotourism and the intention to paying more for it.

This study primarily addresses the behavior of the ecological consumer; although studies in this area exist, the results to date have not been conclusive (Miguens et al. 2015). For Manrai and Manrai (2011), culture influences tourist behavior, whether the motivation for the trip, the decision making, or the behavior behind the decision making. However, this subject has been little studied in the literature (Meng 2010, Hwang and Lee 2018). In addition, after reviewing the diverse literature, we did not find cross-cultural studies that examine the constructs of Stern's model (2000). The absence of such studies is probably due to the lack of employability of the theory of reasoned action or planned behavior, which is generally used in studies investigating the moderating and mediating effects of culture (Baron and Kenny 1986).

On the other hand, different studies have indicated that conceptual models that combine theories based on prosocial motivations and individual motives better explain the variance of behaviors or intentions of proenvironmental behaviors (Bamberg et al. 2007, Bamberg and Möser 2007). For example, there is utility in combining the VBN theory (Stern 2000) and the TPB in a conceptual model.

Research on the ecological behavior of consumers, and specifically in the field of tourism, is scarce in terms of knowledge of the importance of psychosocial factors, attitudes, or sociocultural factors (Weaver and Lawton 2007, do Paço and Raposo 2009, Han 2015, Hultman et al. 2015, Kvasova 2015, Kiatkawsin and Han 2017).

Furthermore, the literature review emphasizes the need to deepen the understanding of environmentally responsible behavior by incorporating the external, contextual, or group variables that influence such behavior (Miguens et al. 2015). In addition, scant research exists on the relationship between personality traits and the environmentally responsible behavior of individuals in the tourism industry (Kvasova 2015). It is important to remember that ecotourists are a type of consumer with their own characteristics; they are interested in environmental conservation and the cultural preservation of the places they visit as well as experiencing and learning new things from the natural environment (Juric et al. 2002). Therefore, it is interesting to apply the VBN model to the environmental context (Stern et al. 1999). In addition, as Chen (2015) indicated, social values and norms are essential in the understanding of so-called ecological behaviors, which is why we use the VBN model (Stern et al. 1995, 1999, Stern 2000). In the field of tourism (Han 2015, Hultman et al. 2015, Kvasova 2015, Kiatkawsin and Han 2017), where environmental values, attitudes, beliefs, and norms are interrelated, this model is of great interest, particularly if we combine it with the TPB (Ajzen 1991) to improve the explanatory capacity of the proposed model (Bamberg et al. 2007, Bamberg and Möser 2007). The VBN model is based on the confluence of the theory of values (Schwartz and Bilsky 1987), the model of 
normative influence (NAM; Schwartz 1977), and the new ecological paradigm (NEP; Van Liere and Dunlap 1978). The first theory adopts the traditional conception of values as principles that guide the development of attitudes, the explanation from the NAM model of the mechanism that drives individuals to adopt altruistic behaviors, and the concept of social conscience about the effects of human actions on the biosphere or an environmental vision of the world from the NEP. In sum, it is a model in which personal norms are activated in the consciousness of the consequences of unsustainable behaviors on the environment through people's beliefs in accepting responsibility for the impact of their behavior on the environment.

This research differs from existing studies in some interesting ways. First, we wanted to create a comprehensive model that combines several models, an unusual approach to studying ecological behavior in tourism services (Han 2015). Therefore, we proposed a comprehensive application of the VBN model (Stern et al. 1999) to the tourism sector, which is an innovative contribution to this field of research because previous studies have used only portions of this model to explain consumer ecological behaviors (Choi et al. 2015). Additionally, following the example of Choi et al. (2015), we incorporated the construct of personal norms from the TPB to determine how the intention to undertake ecotourism and the intention to pay more for ecotourism relate to the VBN model. Thus, we created a broader model capable of collecting more variables that, according to our hypotheses, may influence ecotourists' behavior. Finally, we incorporated sociodemographic factors into the research because these factors have been considered unimportant in the models of various previous investigations and in many cases have been underestimated by researchers (do Paço and Raposo 2009).

Regarding methodology, we conducted a cross-cultural study of the ecological behavior factors of ecotourists in two countries (Spain and Chile) given the importance of ecotourism in these regions. Nel-lo and Llanes (2016) point out that ecotourism represents $10 \%$ of worldwide tourism. Moreover, for the countries chosen for our research, we found the following relevant data: 2.7 million visits to nature parks in Chile and more than 14 million visits to Spain (SENATUR 2015). Chile is especially interesting given its effort in 2017 to create new nature parks, resulting in the protection of $20 \%$ of its total national territory (Cué 2017). Spain has protected $13 \%$ of its natural areas, and more than $27 \%$ of these areas are included in the Natura Network. In Spain, nature tourism accounts for between $12 \%$ and $29 \%$ of tourist activity (MAPAM 2017). Regarding the importance of ecological tourism, we must point out that $70 \%$ of Chile attracts nature tourism (Notiamérica 2015); specifically, Chilean natural areas received 3,019,432 visits, of which $71.4 \%$ were national and the rest foreign (Senatur 2017).

To understand the differences between the two countries, we used the cultural dimensions developed by G. Hofstede (Hofstede Insights 2018). We adopted this approach because cultural values influence every aspect of human life: personality, lifestyle, psychology, and motivation (Manrai and Manrai 2011). Hofstede's dimensions facilitate analysis on a national level and are standardized to allow multiple and easier comparisons between countries.

According to Hofstede (Hofstede Insights 2018), the cultural dimensions and their values for Spain and Chile are as follows:
1. Power distance index (PDI): reflects the perception that members of society have an unequal distribution of power and the extent to which this inequality is accepted in a society. The PDI for Chile (63) is higher than that for Spain (57).

2. Individualism (IDV): level at which the individuals of a country tend to see themselves as self-sufficient individuals (individualists) compared to a tendency to see themselves, above all, as part of a social group (collectivists). The IDV in Spain (51) is higher than that in Chile (23), indicating that Spanish society has more individualist attitudes and fewer ties with others.

3. Masculinity (MAS): level at which values such as assertiveness, performance, success, and competitiveness prevail in a culture over values such as kindness, quality of life, maintaining warm personal relationships, service, and caring for the weak. The MAS score for Chile is very low (28) compared to that for Spain (42), which indicates that Chile has a more feminine culture.

4. Uncertainty avoidance index (UAI): level at which individuals in a given culture feel uncomfortable with uncertainty and ambiguity. For this variable, Chile and Spain have the same score (86).

Therefore, because of the lack of research in this area, the aim of this study was to apply a cross-cultural perspective to determine the internal and external factors that influence the behaviors of consumers identified as ecotourists (tourists who engaged in ecological consumption in the previous year), behaviors that lead them to take environmentally responsible trips that conserve the environment and support the well-being of the local community, as well as the factors that shape their purchasing intentions. In sum, we developed a comprehensive model to holistically explain the variables that act on ecological behavior or that affect the intentions of both undertaking and paying more for ecotourism, thus enabling a better understanding of the characteristics of ecotourists on which the thriving ecotourism market depends.

\section{METHODS}

To conduct this study, we began with several previous studies that reveal the importance of the ecological behavior of tourists. These studies address tourists' values (Han 2015, Kiatkawsin and Han 2017), environmental beliefs (van Riper and Kyle 2014), awareness of consequences (Han 2015, Kiatkawsin and Han 2017), assignment of responsibility (Kiatkawsin and Han 2017), personal norms (Choi et al. 2015), subjective norms (Lu et al. 2016), ecotourism intentions (Laroche et al. 2001, Hultman et al. 2015, Lu et al. 2016), and intention to pay more (for ecotourism; Laroche et al. 2001, Hultman et al. 2015, Lu et al. 2016).

Developed by Stern et al. (1999), the VBN model is a comprehensive model that uses a psychological approach. The VBN is a hierarchical model that derives its robustness from a successive chain of elements that, when faced with an ecological or environmental problem, directly or indirectly activate the next element.

The VBN theory is based on three preceding theories: Schwartz's theory of basic human values (Schwartz and Bilsky 1987), the PNI model (Schwartz 1977), and the NEP (Van Liere and Dunlap 1978). From the theory of basic human values, the VBN theory 
adopts the traditional conception of values-principles that guide the development of attitudes. In addition, the VBN theory draws on the PNI model for an explanation of the mechanism that drives individuals to adopt altruistic behavior. Last, from the NEP, the VBN theory derives the notion of social awareness regarding the effects of human activity on the biosphere, an environmental perspective of the world. The VBN model has been used in tourism to examine consumption in ecofriendly hotels (Choi et al. 2015, Han 2015), the environmental behavior of young travelers (Kiatkawsin and Han 2017), and recreational behavior (Lee and Jan 2018). Table 1 presents the different constructs analyzed in this study as well as the items used to measure each variable.

We applied a questionnaire as an instrument to collect data from the sample units in Chile and Spain. The questionnaire consisted of more than 80 closed-ended, dichotomous (or multichotomous/ polytomous), and multiple-choice questions as well as one openended question. The purpose of the questionnaire was to obtain information about the trips taken by the respondents and about their values, beliefs, subjective and personal norms, behavioral intention, and willingness to pay a potential premium. The closedended questions were scored on a five-point Likert scale ranging from 1 "completely disagree" to 5 "completely agree," and the open question requested the respondent's age. The questionnaire was distributed and completed online through a market research company.

The final sample consisted of 406 Chilean and 403 Spanish tourists; thus, the margin of error is lower than $5 \%$ for a confidence level of $95 \%$. The percentages in the sample were very similar to those in the overall tourist population (SENATUR 2013, INE 2016). We selected Chile and Spain given the significance of nature-based tourism for their economies: 2.7 million visits to Chile and more than 14.4 million visits to nature parks in Spain (SENATUR 2015, EUROPARC 2016).

The main objective of this study is to analyze the relationships between the latent variables of Chile and Spain to understand the keys to people's intentions to undertake ecotourism and, consequently, to pay more to do so. Therefore, the base model selected to test our hypotheses is the VBN (Stern et al. 1999), as previously explained.

Most of the research carried out with the VBN model has opted to work with biospheric values. These values are guiding principles of people's lives that represent concern for nonhuman species and the biosphere as a whole (Aguilar 2006). Research has shown that they influence attitudes toward the environment in terms of behaviors (Dietz et al. 1998, Han 2015, Kiatkawsin and Han 2017) and that these values are maintained (de Groot and Steg 2008) in both daily life and behavior related to tourism (Lee and Jan 2018). Meanwhile, van Riper and Kyle (2014) point out that selfish values have a negative effect on personal norms, and biospheric and altruistic values have a positive influence on personal norms.

As mentioned above, biospheric values, according to Aguilar (2006), are guiding principles of people's lives that represent concern for nonhuman species and for the biosphere as a whole. Social/altruistic values, according to Aguilar (2006), are guiding principles of people's lives that represent concern for the well- being of others. These values are manifested through social justice, utility, equality, and a peaceful world. Egocentric/egoist values, according to Aguilar (2006), are those that represent concern for oneself. The items or variables that help us identify egocentric values are authority, wealth, social power, and influence. Thus, Stern (2000) points out that environmental concern is promoted by collective or altruistic values, that biospheric values refer to the biosphere and other species, and that selfish values refer to an individual's own interest. Van Riper and Kyle point out that biospheric and altruistic values are expected to be positive in their influence on the environmentalism of individuals and that selfish values are expected to have a converse influence; these values also affect the moral obligation that precedes proenvironmental behavior (Stern et al. 1995).

In sum, taking into account the difference between the probiosphere and other-species view of biospheric values and the anthropocentric and self-interested view of selfish values (Stern 1999), there are differences in the effects of these values on environmental attitudes. Selfish values have a negative effect on environmental beliefs in comparison to biospheric and altruistic values, which favor proenvironmental attitudes (van Riper and Kyle 2014, Choi et al. 2015).

As explained previously, according to Stern (2000), values are the first element to influence consumer behavior and to activate beliefs. The NEP is one of the belief constructs in the VBN model. Based on Dunlap et al. (2000:427), the NEP refers to "beliefs about humanity's ability to alter the balance of nature and the existence of limits to growth for human societies." Dunlap and Van Liere (1978) created a 4-point Likert scale with 12 items chosen from a total of 35 in their 1976 study of the ideas of Washington State residents on the environment, pollution, population, and natural resources; nine items were related to the NEP and the rest to the dominant social paradigm (DSP). The scale has different dimensions or ideas: the limits of growth, the natural balance, and the anthropocentric vision of the environment. In 2000, Dunlap et al. (2000) carried out a review of the NEP with some improvements, including "taking advantage of a wider range of facets of an ecological worldview; offering a balanced set of pro and anti-NEP articles; and updating terms" (p.425).

Environmental problems stem from the values, attitudes, and beliefs of societies, such as individualism, progress or abundance, free enterprise or respect for quality of life. From this perspective, the DSP encompasses the vision of the world or way of interpreting it. This paradigm must be overcome by a more realistic vision of the world in the face of ecological problems and the inevitable limits to growth in favor of balance with nature and the rejection of the anthropocentric view; this new vision of the world is the NEP (Dunlap and Van Liere 1978). Dunlap et al. (2000) modified the NEP to 15 items scored on a 5-point Likerttype scale, updated the terms and made them gender neutral. The new NEP included three additional items in five dimensions with two new items: the rejection of the concept of humans as the most exceptional species and the belief in ecological crises. The items were distributed in two parts, with seven items related to the NEP and six to the DSP; four of the original items were modified, and six were maintained. 
Table 1. Items included in the model.

\begin{tabular}{|c|c|c|c|}
\hline & Construct & Items & Academic sources \\
\hline \multirow[t]{4}{*}{ Biospheric values } & BV1 & The most important thing in my tourist trip is the protection of the environment and to preserve nature. & Stern (2000), Han (2015), \\
\hline & BV2 & The most important thing in my tourism trip is to prevent pollution. & Kiatkawsin and Han (2017) \\
\hline & BV3 & $\begin{array}{l}\text { The most important thing in my tourism trip is to respect the earth and to be in harmony with other } \\
\text { species. }\end{array}$ & \\
\hline & BV4 & The most important thing in my tourist trip is harmony with nature and to fit in with nature. & \\
\hline \multirow[t]{4}{*}{ Altruistic values } & AV1 & $\begin{array}{l}\text { The most important thing in my tourism trip is social justice, that is, to correct injustice and care for the } \\
\text { vulnerable. }\end{array}$ & $\begin{array}{l}\text { Stern (2000), Han (2015), } \\
\text { Kiatkawsin and Han (2017) }\end{array}$ \\
\hline & AV2 & The most important thing in my tourism trip is to be useful and to work for the well-being of others. & \\
\hline & AV3 & The most important thing in my tourism trip is equality and equal opportunity for all. & \\
\hline & AV4 & The most important thing in my tourism trip is peace in a world that is free of wars and conflict. & \\
\hline \multirow[t]{4}{*}{ Selfish values } & SV1 & The most important thing in my tourism trip is authority and the right to lead or command. & Stern (2000), Han (2015), \\
\hline & SV2 & The most important thing in my tourism trip is social power, control over others, and authority. & Kiatkawsin and Han (2017) \\
\hline & SV3 & The most important thing in my tourism trip is wealth, such as material possessions and money. & \\
\hline & SV4 & $\begin{array}{l}\text { The most important thing in my tourism trip is to be influential and to have an impact on people and } \\
\text { events. }\end{array}$ & \\
\hline \multirow{15}{*}{$\begin{array}{l}\text { New ecological } \\
\text { paradigm }\end{array}$} & NEP1 & We are approaching the maximum number of people that the Earth can support or maintain. & Dunlap et al. (2000), van \\
\hline & NEP2 & Humans have the right to modify the natural environment to meet their needs. & Riper and Kyle (2014) \\
\hline & NEP3 & When human beings interfere with nature, the consequences are often disastrous. & \\
\hline & NEP4 & Technological development will prevent us from making the Earth uninhabitable. & \\
\hline & NEP5 & Human beings are severely abusing the environment. & \\
\hline & NEP6 & The Earth has abundant natural resources and we just have to learn how to develop them. & \\
\hline & NEP7 & Plants and animals have as much of a right to exist as do human beings. & \\
\hline & NEP8 & The balance of nature is strong enough to adjust to the impacts of modern industrial countries. & \\
\hline & NEP9 & Despite our special abilities, human beings are still subject to the laws of nature. & \\
\hline & NEP10 & The so-called "ecological crisis" of humanity has been highly exaggerated. & \\
\hline & NEP11 & The earth is like a spaceship with very limited space and resources. & \\
\hline & NEP12 & Human beings were created to exert authority over nature. & \\
\hline & NEP13 & The balance of nature is very delicate and is easily disturbed. & \\
\hline & NEP14 & Human beings will learn enough about how nature works to enable them to control it. & \\
\hline & NEP15 & If things continue in the same way, we will soon experience a major ecological catastrophe. & \\
\hline \multirow[t]{8}{*}{$\begin{array}{l}\text { Awareness of } \\
\text { consequences }\end{array}$} & $\mathrm{AC} 1$ & $\begin{array}{l}\text { I think that climate change, sometimes referred to as the greenhouse effect, will be a very serious problem } \\
\text { for me and my family. }\end{array}$ & $\begin{array}{l}\text { Stern (2000), Ibtissem (2010), } \\
\text { Han (2015), Kiatkawsin and }\end{array}$ \\
\hline & $\mathrm{AC} 2$ & I think that climate change is going to be a very serious problem for the country as a whole. & Han (2017) \\
\hline & AC3 & I think that climate change is going to be a very serious problem for plants and animals. & \\
\hline & $\mathrm{AC} 4$ & I think that the problem of deforestation is going to be a serious problem for me and my family. & \\
\hline & AC5 & I believe that deforestation will be a very serious problem for the country as a whole. & \\
\hline & AC6 & $\begin{array}{l}\text { I think that the problem of toxic substances in the air, water, and soil will be a serious problem for me and } \\
\text { my family. }\end{array}$ & \\
\hline & AC7 & $\begin{array}{l}\text { I believe that toxic substances in the air, water, and soil will be a very serious problem for the country as a } \\
\text { whole. }\end{array}$ & \\
\hline & AC8 & $\begin{array}{l}\text { I believe that toxic substances in the air, water, and soil will be a very serious problem for other species of } \\
\text { plants and animals. }\end{array}$ & \\
\hline \multirow{3}{*}{$\begin{array}{l}\text { Assignment of } \\
\text { responsibility }\end{array}$} & AR1 & I think that tourists are partly responsible for the environmental problems caused by the tourism industry. & Kiatkawsin and Han (2017) \\
\hline & AR2 & I feel that each tourist is responsible for the environmental harm caused by each trip taken. & \\
\hline & AR3 & $\begin{array}{l}\text { I believe that each traveler should take responsibility for the environmental problems caused during their } \\
\text { travels. }\end{array}$ & \\
\hline \multirow[t]{6}{*}{ Personal norms } & PN1 & I would be a better person if I stay in a green hotel and use environmentally friendly products and services. & Choi et al. (2015) \\
\hline & PN2 & I feel morally obligated to stay in an ecofriendly hotel than in a conventional hotel. & \\
\hline & PN3 & People like me should do all that they can to conserve the environment. & \\
\hline & PN4 & I feel compelled to always bear in mind the environment and nature when I travel. & \\
\hline & PN5 & I feel morally obligated to use a green hotel regardless of what others do. & \\
\hline & PN6 & I feel personally obligated to conserve as much energy as possible. & \\
\hline \multirow[t]{3}{*}{ Social norms } & SN1 & Most of the people who are important to me believe that I should choose ecotourism when I travel. & Lu et al. (2016) \\
\hline & SN2 & Most of the people who are important to me want me to choose ecotourism when I travel. & \\
\hline & SN3 & The people whose opinions I value prefer that I choose ecotourism when I travel. & \\
\hline \multirow{4}{*}{$\begin{array}{l}\text { Intention to } \\
\text { practice } \\
\text { ecotourism }\end{array}$} & $\mathrm{IC} 1$ & It is very possible that I will visit an ecological or ecotourism destination soon. & Laroche et al. (2001), \\
\hline & IC2 & I want to visit an ecological or ecotourism destination. & Hultman et al. (2015), Lu et \\
\hline & IC3 & I intend to visit an ecological destination in the foreseeable future. & al. $(2016)$ \\
\hline & IC4 & I will visit an ecological destination within the next 12 months. & \\
\hline \multirow{7}{*}{$\begin{array}{l}\text { Intention to pay } \\
\text { more for } \\
\text { ecotourism }\end{array}$} & IPM1 & I am willing to take a more expensive ecological vacation to reduce pollution. & Laroche et al. (2001), \\
\hline & IPM2 & I am willing to financially support ecological tourism or ecotourism projects. & Hultman et al. (2015), Lu et \\
\hline & IPM3 & $\begin{array}{l}\text { I am willing to pay more for ecological tourism or ecotourism if I knew the additional cost paid for a } \\
\text { better environment. }\end{array}$ & al. (2016) \\
\hline & IPM4 & $\begin{array}{l}\text { I am willing to pay more for ecological tourism or ecotourism today to possibly have better tourism } \\
\text { experiences in the future. }\end{array}$ & \\
\hline & IPM5 & I am willing to spend more money for ecological tourism or ecotourism than for "normal" tourism. & \\
\hline & IPM6 & It is easier for me to pay more money for accommodations in an establishment with ecofriendly practices. & \\
\hline & IPM7 & I am willing to pay more money for ecological lodging in my vacations. & \\
\hline
\end{tabular}


Ecologically responsible behavior can be considered altruistic behavior and depends on the activation of personal norms, which, in turn, are a function of an individual's values. The activation of personal rules by values is explained by two other variables.

The first variable is the assignment of responsibility, understood as the degree to which an individual feels responsible for the impact of his or her conduct on the environment (Schwartz 1977). The second variable is awareness of the consequences of the action or, in other words, the specific beliefs associated with the behavior. It comes from Schwartz's (1992) model, which points out that knowledge of the consequences refers to the fact that individuals tend to realize the consequences of their behaviors for others. Personal norms are, according to Schwartz and Howard (1981:191), the "moral obligation to take or refrain from specific actions." Personal norms are key among the elements within the VBN model for the predisposition to become a behavior (Stern 2000)

Choi et al. (2015) point out that a person with strong personal norms has greater intentions to visit an ecological hotel than a person without them. Personal norms are also important for consumption-restricting behaviors (Jansson et al. 2010).

H1. Biospheric values positively influence the new ecological paradigm.

H2. Selfish values negatively influence the new ecological paradigm.

H3. The new ecological paradigm positively influences the awareness of consequences.

Regarding the awareness of consequences, several studies have pointed out its relationship with the assignment of responsibility in the field of ecological consumption and tourism (Stern et al. 1995, Ibtissem 2010, van Riper and Kyle 2014, Choi et al. 2015, Kiatkawsin and Han 2017), and others have demonstrated its relationship to personal norms and behavioral intentions (Wynveen et al. 2015).

H4. Awareness of consequences positively influences the assignment of responsibility.

H5. Awareness of consequences positively influences personal norms.

H6. Awareness of consequences positively influences intentions to undertake ecotourism.

Similarly, the relationship of the influence between the assignment of responsibility and personal norms has been widely acknowledged in the literature that applies the VBN model (Stern et al. 1999, de Groot and Steg 2008, Ibtissem 2010, van Riper and Kyle 2014, Choi et al. 2015, Kiatkawsin and Han 2017).

H7. The assignment of responsibility positively influences the personal norms of tourists.

Several studies have noted the positive relationship between the proenvironmental personal norms of tourists and their intentions to behave in an ecofriendly way when traveling (Kiatkawsin and Han 2017) or to stay in ecofriendly hotels (Choi et al. 2015, Han 2015) as well as their intentions to pay more for an ecological activity or cruise (Han 2015).
H8. Personal norms positively influence intentions to undertake ecotourism.

H9. Personal norms positively influence intentions to pay more to undertake ecotourism.

Han et al. (2017) study the positive influence of subjective norms on the intention to revisit ecofriendly hotels; other studies examine behaving appropriately in an ecological museum (Han and Hyun 2017) and undertaking ecotourism activities on a trip (Lee and Jan 2018). Additionally, Han (2015) offers a comprehensive view of the formation of proenvironmental intentions by travelers staying in ecofriendly lodgings. This author notes that subjective norms influence the personal norms (sense of duty) of the VBN model as well as behavioral intentions.

H10. Subjective norms positively influence personal norms.

H11. Subjective norms positively influence intentions to undertake ecotourism.

Regarding the intentions of ecotourists to pay more, we note that a study by Hultman et al. (2015) on the intentions to pay higher prices for visiting ecotourism sites applies postmaterialist theory and the TPB. A study by López-Mosquera (2016) is in a similar vein, although it is related to higher prices paid for visiting a nature park.

H12. The intention to undertake ecotourism positively influences the intention to pay more to undertake ecotourism.

The proposed model was evaluated using partial least squares structural equation modeling (PLS-SEM). The most important reason to select PLS-SEM instead of covariance-based SEM (CBSEM) is the research goal. The primary purpose of the PLS approach is to predict the indicators by means of the component's expansion (Jöreskog and Wold 1982). This method is accepted as a key multivariate statistical technique to estimate cause-effect relationships between constructs in international marketing research and across different groups of respondents. Additionally, the PLS algorithm is well suited to our case because it imposes fewer restrictions on data normality and because a predictive model is used (Anderson and Gerbing 1988, Cepeda and Roldán 2004, Sarstedt et al. 2014). We conducted the analysis in two stages. First, we developed a general model, and second, we applied the model to the two categories of Chile and Spain. In sum, Table 2 shows all hypotheses included in the causal model.

\section{RESULTS}

To perform the data analysis, we applied a model based on the PLS-SEM method (Hair et al. 2014, Sarstedt et al. 2014) using Smart PLS 3.0 software (Ringle et al. 2017). To determine the stability of the estimates, we tested the data using 2500 subsamples. Next, we analyzed the reliability and validity of the proposed general model and then evaluated it (Anderson and Gerbing 1988).

To determine the suitability of the proposed model, this study met the criteria for internal reliability and validity, content validity, and convergent and discriminant validity. As shown in Table 3, the values for Cronbach's alpha confirm the reliability of the scales. These values range from a maximum of 0.948 to a minimum of 0.694 and are therefore higher than or approximately equal to the recommended values for scale robustness (Nunnally 
1978). The composite reliability of the model fluctuates between 0.823 and 0.957 , thus exceeding the 0.7 threshold indicated by Nunnally (1978). In addition, the average variance extracted (AVE) of each construct was analyzed, revealing values greater than the suggested 0.5 (Fornell and Larcker 1981) except for the NEP construct (0.404). This result indicates that this construct is difficult to explain using its constituent variables.

Table 2. Hypotheses of the model.

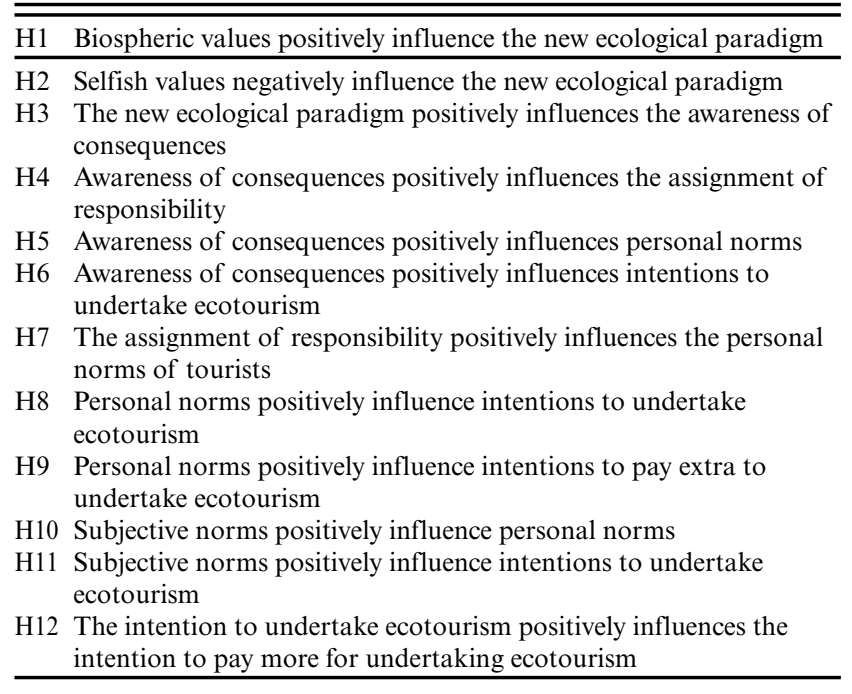

Convergent validity is verified by analyzing the factor loadings and their significance. The individual item loadings in our model are higher than 0.6 (Bagozzi and Youjae 1988). Additionally, we checked the significance of the loadings with a resampling procedure (500 subsamples) to obtain t-statistic values, which were all significant $(\mathrm{p}<0.001)$. This finding supports the convergent validity of the indicators (Hair et al. 2014).

Discriminant validity indicates the extent to which a given construct is different from other latent variables. This research adopted the Fornell and Larcker (1981) criteria of discriminant validity to examine whether the square root of the AVE for each construct exceeded the correlation of the construct and other constructs in the model. As shown in Table 4, all diagonal values exceeded the interconstruct correlations, thereby demonstrating adequate discriminant validity of all constructs.

To evaluate the predictive capacity of the structural model, we analyzed the independent variables through the variance of the endogenous variables that are able to explain the constructs that predict them (Cepeda and Roldán, 2004). Regarding the optimal values of this predictive level, we applied the Falk and Miller (1992) method, which requires the $\mathrm{R}^{2}$ value of the constructs to be greater than 0.1 . Our results show that all values are greater than 0.1 . Therefore, the most significant variables included in the model were able to explain 0.363 of the variance in the intention to pay more for ecotourism (Table 5).

Regarding the global adjustment indicators, we applied a goodness-of-fit (GoF) index. The values of the GoF index varied between 0 and 1 ; it is usually recommended that they be higher than 0.31 (Chin 1998) to indicate acceptable model fit. The result for our general model fit was 0.459 .

Regarding our hypotheses, we note that all hypotheses were confirmed (Table 5) at $10 \%$ and that 11 hypotheses were confirmed at $5 \%$; the exception was hypothesis 6 , which measures the relationship between awareness of consequences and the intention to undertake ecotourism.

We observed some differences in the proposed general model between Chile and Spain, which could be caused by cultural differences. We incorporated the moderating effect of culture into the model and aligned it with our proposed methodology using the multigroup PLS technique.

Table 5 presents the results of the multigroup analysis. We did not observe significant differences in any of the 12 hypotheses at $\mathrm{p}<$ 0.01 or even at $p<0.05$. These results indicate that there is no moderating effect of culture or country of residence in the way that we stated the hypotheses. This finding may signify either the robustness of the model or that, despite the different results for the cultural dimensions, the cultures are not sufficiently different. Figure 1 illustrates the hypothesis test for the global model.

\section{DISCUSSION AND CONCLUSIONS}

Managing for sustainable development and resource extraction requires an understanding of the feedback between biophysical systems and humans and thus requires an integrative, interdisciplinary approach. Such feedback is part of SES in which resources, actors, and governance systems interact to produce outcomes across the component parts (Cox et al. 2010, McGinnis and Ostrom 2014). Within the tourism framework, the growth of ecotourism as a form of alternative tourism has prompted the tourism industry to become increasingly interested in understanding the factors that affect, influence, or moderate the behavior of people who undertake ecotourism. The purpose of this research study was to examine the ecological behavior of the ecotourist.

Our study is based on the VBN model (Stern et al. 1999) complemented by a TPB construct (Choi et al. 2015), personal norms, to explain the behavioral intentions of ecotourists as consumers of products or services from a cross-cultural perspective (two countries, Chile and Spain) as well as their intention to pay more for ecotourism. The results confirm the robustness of the model because there are no significant differences between the countries, which indicates that ecotourism behavior is similar regardless of the country of origin.

We demonstrated that values directly influence environmental beliefs. Biospheric values, which guide life principles that represent concern for nonhuman species and the biosphere as a whole, have a positive influence, and selfish values, which represent concern for oneself, have a negative influence. Therefore, the biospheric orientation is related to the intention for ecological behavior, as opposed to selfish behavior (Stern et al. 1995). In sum, regarding environmental values and beliefs, the model indicates the existence of a significant relationship between biospheric values, similar to the findings of other studies (Stern et al. 1995, 1999, Ibtissem 2010, Choi et al. 2015). In contrast to studies such as Lee and Jan (2018), it also usefully considers selfish values, such as differences in the use of selfish values. However, 
Table 3. Internal consistency and convergent validity.

\begin{tabular}{|c|c|c|c|c|c|c|}
\hline Construct & Indicator & Loading* & $\begin{array}{l}\text { Average Variance } \\
\text { Extracted (AVE) }\end{array}$ & Cronbach's alpha & $\begin{array}{c}\text { Composite } \\
\text { Reliability (CR) } \\
\end{array}$ & $\mathrm{R}^{2}$ \\
\hline \multirow[t]{4}{*}{ Biospheric values } & BV1 & 0.878 & 0.759 & 0.893 & 0.926 & \\
\hline & BV2 & 0.888 & & & & \\
\hline & BV3 & 0.918 & & & & \\
\hline & BV4 & 0.796 & & & & \\
\hline \multirow[t]{4}{*}{ Selfish values } & SV9 & 0.828 & 0.742 & 0.886 & 0.920 & \\
\hline & SV10 & 0.903 & & & & \\
\hline & SV11 & 0.906 & & & & \\
\hline & SV12 & 0.804 & & & & \\
\hline \multirow{8}{*}{$\begin{array}{l}\text { New ecological } \\
\text { paradigm }\end{array}$} & NEP2 & 0.617 & 0.404 & 0.788 & 0.843 & 0.291 \\
\hline & NEP5 & 0.626 & & & & \\
\hline & NEP7 & 0.668 & & & & \\
\hline & NEP8 & 0.648 & & & & \\
\hline & NEP10 & 0.710 & & & & \\
\hline & NEP12 & 0.659 & & & & \\
\hline & NEP13 & 0.508 & & & & \\
\hline & NEP15 & 0.645 & & & & \\
\hline \multirow{8}{*}{$\begin{array}{l}\text { Awareness of } \\
\text { consequences }\end{array}$} & $\mathrm{AC} 1$ & 0.847 & 0.735 & 0.948 & 0.957 & 0.421 \\
\hline & $\mathrm{AC} 2$ & 0.877 & & & & \\
\hline & $\mathrm{AC} 3$ & 0.876 & & & & \\
\hline & AC4 & 0.850 & & & & \\
\hline & AC5 & 0.870 & & & & \\
\hline & AC6 & 0.850 & & & & \\
\hline & AC7 & 0.860 & & & & \\
\hline & AC8 & 0.827 & & & & \\
\hline \multirow{3}{*}{$\begin{array}{l}\text { Assignment of } \\
\text { responsibility }\end{array}$} & AR1 & 0.697 & 0.61 & 0.694 & 0.823 & 0.115 \\
\hline & AR2 & 0.797 & & & & \\
\hline & AR3 & 0.842 & & & & \\
\hline \multirow[t]{6}{*}{ Personal norms } & PN1 & 0.673 & 0.541 & 0.828 & 0.875 & 0.418 \\
\hline & PN2 & 0.813 & & & & \\
\hline & PN3 & 0.669 & & & & \\
\hline & PN4 & 0.768 & & & & \\
\hline & PN5 & 0.789 & & & & \\
\hline & PN6 & 0.685 & & & & \\
\hline \multirow[t]{3}{*}{ Social norms } & SN1 & 0.937 & 0.879 & 0.931 & 0.956 & \\
\hline & SN2 & 0.960 & & & & \\
\hline & SN3 & 0.925 & & & & \\
\hline \multirow{4}{*}{$\begin{array}{l}\text { Intention to practice } \\
\text { ecotourism }\end{array}$} & IC1 & 0.827 & 0.718 & 0.869 & 0.910 & 0.265 \\
\hline & $\mathrm{IC} 2$ & 0.826 & & & & \\
\hline & IC3 & 0.898 & & & & \\
\hline & IC4 & 0.836 & & & & \\
\hline \multirow{7}{*}{$\begin{array}{l}\text { Intention to pay } \\
\text { more for ecotourism }\end{array}$} & IPM5 & 0.816 & 0.697 & 0.926 & 0.941 & 0.363 \\
\hline & IPM6 & 0.741 & & & & \\
\hline & IPM7 & 0.894 & & & & \\
\hline & IPM8 & 0.891 & & & & \\
\hline & IPM9 & 0.881 & & & & \\
\hline & IPM10 & 0.794 & & & & \\
\hline & IPM11 & 0.897 & & & & \\
\hline
\end{tabular}

Note: ${ }^{*}$-value $<0.05$

the proposed model does not use indicators for social/altruistic values, which differentiates it from previous studies indicated (Stern et al. 1995). Therefore, the idea of the "benefits and costs for others" is not incorporated into the model, in contrast to studies such as Ibtissem (2010), van Riper and Kyle (2014), and Han et al. (2017).

The NEP is a highly laborious construct. Despite the fact that the questionnaire is a 15-item model, in the proposed general model, we used 9 items: $2,3,5,7,8,10,12,13$, and 15. Other authors have used a varying number of items of the NEP scale; for example, the analysis of Stern et al. (1999) used 7 items. The relationship between biospheric and selfish values in the NEP is once again empirically contrasted, as in other studies (e.g., Stern et al. 1999, de Groot and Steg 2008, Ibtissem 2010, van Riper and Kyle 2014, Choi et al. 2015, Han 2015, Yeboah and Kaplowitz 2016, Kiatkawsin and Han 2017). It is worth noting that the NEP, which is a measure of the endorsement of a "proecological" world view, is very important in this model and has a strong influence on awareness of consequences.

Awareness of consequences is the main construct that hypotheses rely on in this model; it is related to the ascription of responsibility, personal norms, and the intention of practicing ecotourism. The study shows the importance of this construct as an essential element of the model (Ibtissem 2010, Jansson et al. 2010, Choi et 
Fig. 1. Hypothesis testing for the global model.

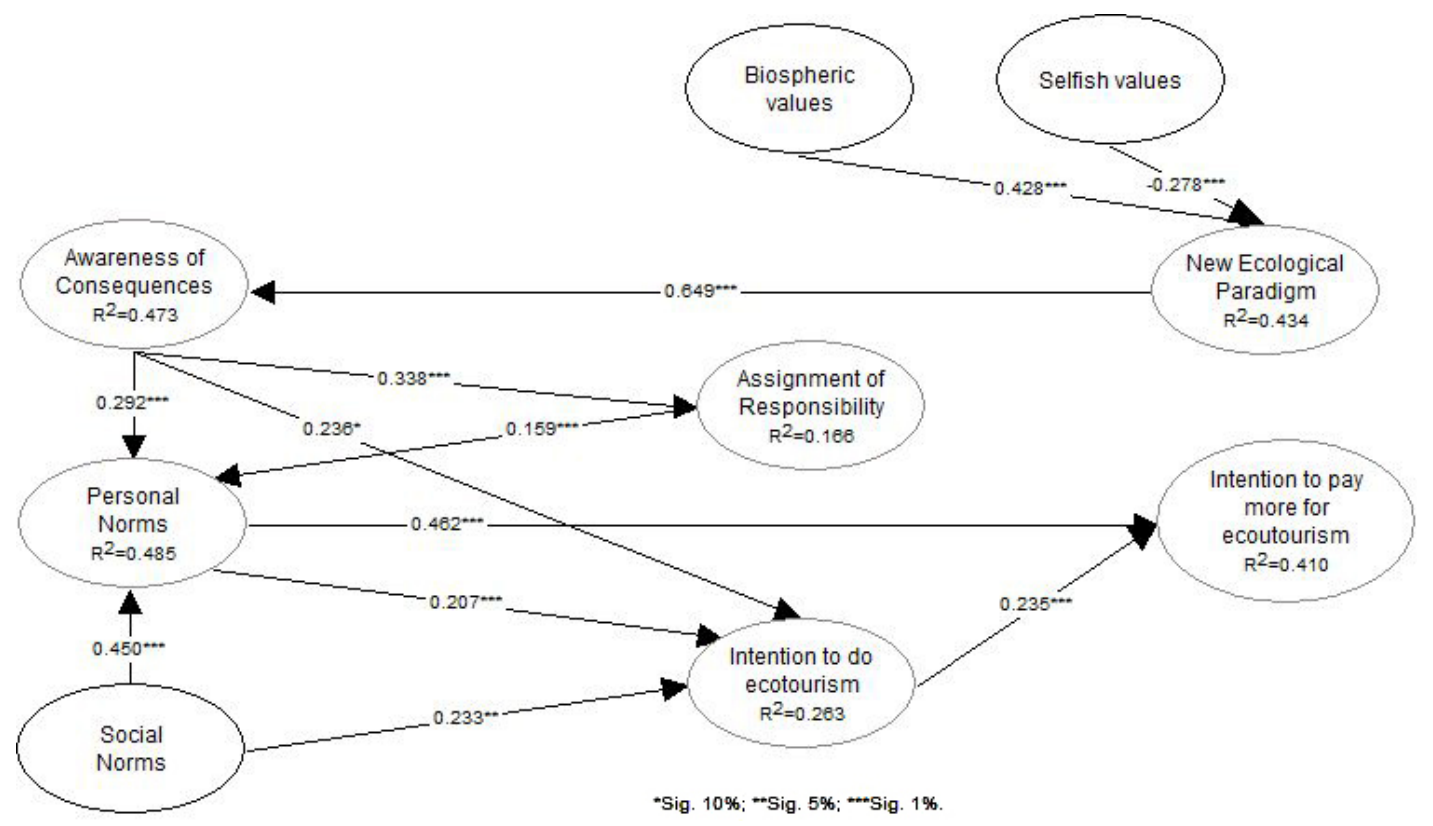

Table 4. Discriminant validity of the theoretical construct measures.

\begin{tabular}{lccccccccc}
\hline \hline & AR & AC & IC & IPM & NEP & PN & SN & BV & SV \\
\hline AR & 0.610 & & & & & & & & \\
AC & 0.338 & 0.735 & & & & & & & \\
IC & 0.280 & 0.365 & 0.718 & & & & & & \\
IPM & 0.260 & 0.243 & 0.435 & 0.697 & & & & & \\
NEP & 0.268 & 0.649 & 0.308 & 0.196 & 0.404 & & & & \\
PN & 0.353 & 0.423 & 0.432 & 0.564 & 0.390 & 0.541 & & & \\
SN & 0.232 & 0.178 & 0.386 & 0.491 & 0.108 & 0.536 & 0.879 & & \\
BV & 0.329 & 0.500 & 0.391 & 0.270 & 0.463 & 0.410 & 0.261 & 0.759 & \\
SV & -0.035 & -0.148 & -0.065 & 0.072 & -0.332 & 0.025 & 0.205 & -0.126 & 0.742 \\
\hline Diagonal elements are the square root of the average variance extracted (AVE) \\
between the constructs and their measures. \\
Off-diagonal elements are correlations between constructs. \\
AR: assignment of responsibility; AC: awareness of consequences; IC: intention \\
to practice ecotourism; IPM: intention to pay more for ecotourism; NEP: new \\
ecological paradigm; PN: personal norms; SN: social norms; BV: biospheric \\
values; SV: selfish values.
\end{tabular}

al. 2015, Kiatkawsin and Han 2017). In sum, the awareness of consequences influences personal norms, the intention to practice ecotourism, and the assignment of responsibility; the latter also influences personal norms.

Initially, the assignment of responsibility was one of the most important constructs in the model (Han 2015, Kiatkawsin and Han 2017), and the same is true in our proposal (Stern et al. 1999, Kaiser et al. 2005, Steg et al. 2005, de Groot and Steg 2008, Ibtissem 2010, van Riper and Kyle 2014, Choi et al. 2015).

Personal norms, such as the assignment of responsibility, are one of the most important constructs of the model because they are seen as a precursor to proenvironmental behaviors (Stern et al. 1999, Itbissem 2010, Kiatkawsin and Han 2017), forms of travel
(Nordlund and Garvill 2003), or the intention to stay in an ecological hotel (Choi et al. 2015). In our model, the results indicate a significant relationship between personal norms and the intention to practice ecotourism, as well as to pay more for it, following the line of previous studies such as Han et al. (2017), Choi et al. (2015), and Yeboah and Kaplowitz (2016).

The subjective norms included in this model or linear framework are adopted from the TPB, and they help us to understand and extend the explanatory framework of the intention of ecotourist behavior intention, following the line of studies such as Goh et al. (2017). Similarly, our model indicates that subjective norms influence personal norms as well as behavior intention (Stern 2000).

Therefore, the intention to practice ecotourism is influenced by awareness of consequences, personal norms, and social norms. Moreover, our research confirms that the intention to practice ecotourism and the intention to pay more for it show a positive relationship, following previous studies by Hultman et al. (2015).

The multigroup analysis of the research indicates that there is no moderating effect in the comparison by country in relation to Chile and Spain. This finding indicates that the model is somewhat robust and, on the other hand, may indicate that the cultural differences between Chile and Spain may not be broad enough in aspects such as moderating ecotourist behavior. We must remember that only the individualism/collectivism and indulgence/control dimensions show dissimilar levels in the two countries; the other dimensions, despite differing, do not have such variant values. The multigroup analysis also indicates that there is no gender moderation effect in any of the hypotheses, which indicates similarity of behavior of the two genders in relation to the general model, despite the differences in masculine/ feminine behavior shown in Hofstede's cultural analysis comparing the two countries. 
Table 5. Summary of hypotheses tests by general model, country, and multigroup.

\begin{tabular}{|c|c|c|c|c|c|c|c|c|c|}
\hline $\begin{array}{l}\text { Hypothesis } \\
\text { number }\end{array}$ & Hypothesis & $\begin{array}{c}\text { General: } \\
\text { Original } \\
\text { Sample } \\
(\mathrm{O})\end{array}$ & $\begin{array}{c}\text { General: T } \\
\text { Statistics } \\
(|\mathrm{O} / \mathrm{STERR}|)\end{array}$ & $\begin{array}{c}\text { Chile: } \\
\text { Original } \\
\text { Sample } \\
(\mathrm{O})\end{array}$ & $\begin{array}{l}\text { Chile: Statistics } \\
(|\mathrm{O} / \mathrm{STERR}|) \mathrm{T}\end{array}$ & $\begin{array}{c}\text { Spain: } \\
\text { Original } \\
\text { Sample }(\mathrm{O})\end{array}$ & $\begin{array}{l}\text { Spain: Statistics } \\
(|\mathrm{O} / \mathrm{STERR}|) \mathrm{T}\end{array}$ & $\begin{array}{l}\text { Multigroup: } \\
\text { T statistics }\end{array}$ & $\begin{array}{c}\text { Multigroup } \\
\text { P-value }\end{array}$ \\
\hline 1/1.a & $\mathrm{BV} \rightarrow \mathrm{NEP}$ & 0.428 & $12.865 * * *$ & 0.282 & $3.326^{* * *}$ & 0.554 & $12.790 * * *$ & 0.271 & 0.393 \\
\hline 2/2.a & $\mathrm{SV} \rightarrow \mathrm{NEP}$ & -0.278 & $5.480 * * *$ & -0.254 & $3.919 * * *$ & -0.279 & $5.437 * * *$ & -0.025 & 0.51 \\
\hline 3/3.a & $\mathrm{NEP} \rightarrow \mathrm{AC}$ & 0.649 & $22.225 * * *$ & 0.603 & $13.524 * * *$ & 0.688 & $21.636^{* * *}$ & 0.147 & 0.442 \\
\hline 4/4.a & $\mathrm{AC} \rightarrow \mathrm{AR}$ & 0.338 & $7.124 * * *$ & 0.215 & $2.868 * * *$ & 0.408 & $7.152 * * *$ & 0.194 & 0.423 \\
\hline $5 / 5 . \mathrm{a}$ & $\mathrm{AC} \rightarrow \mathrm{PN}$ & 0.292 & $7.449 * * *$ & 0.237 & $5.093 * * *$ & 0.35 & $7.595^{* * *}$ & 0.173 & 0.431 \\
\hline 6/6.a & $\mathrm{AC} \rightarrow \mathrm{IC}$ & 0.236 & $1.885^{*}$ & 0.26 & $4.117 * * *$ & 0.118 & $1.940^{*}$ & -0.159 & 0.563 \\
\hline 7/7.a & $\mathrm{AR} \rightarrow \mathrm{PN}$ & 0.159 & $3.408 * * *$ & 0.12 & $2.463 * *$ & 0.187 & $3.440 * * *$ & 0.087 & 0.466 \\
\hline 8/8.a & $\mathrm{PN} \rightarrow \mathrm{IC}$ & 0.207 & $5.358 * * *$ & 0.151 & $2.192 * *$ & 0.36 & $5.361 * * *$ & 0.216 & 0.414 \\
\hline 9/9.a & $\mathrm{PN} \rightarrow \mathrm{IPM}$ & 0.462 & $7.603 * * *$ & 0.472 & $9.464 * *$ & 0.431 & $7.600 * * *$ & -0.056 & 0.522 \\
\hline 10/10.a & $\mathrm{SN} \rightarrow \mathrm{PN}$ & 0.450 & $9.444 * * *$ & 0.484 & $10.858 * * *$ & 0.417 & $9.325 * * *$ & -0.105 & 0.542 \\
\hline 11/11.a & $\mathrm{SN} \rightarrow \mathrm{IC}$ & 0.233 & $2.014 * *$ & 0.264 & $4.359 * * *$ & 0.135 & $1.970 * *$ & -0.138 & 0.555 \\
\hline 12/12.a & $\mathrm{IC} \rightarrow \mathrm{IPM}$ & 0.235 & $5.368 * * *$ & 0.197 & $3.755^{* * *} *$ & 0.307 & $5.261 * * *$ & 0.14 & 0.445 \\
\hline
\end{tabular}

Note: *Sig. $10 \% ; * *$ Sig. $5 \% ; * * *$ Sig. $1 \%$

AR: assignment of responsibility; AC: awareness of consequences; IC: intention to do ecotourism; IPM: intention to pay more for ecotourism; NEP: new ecological paradigm; PN: personal norms; SN: social norms; BV: biospheric values; SV: selfish values.

$\mathrm{R}^{2}$ values - general model: $\mathrm{R}^{2}(\mathrm{NEP}): 0.291 ; \mathrm{R}^{2}(\mathrm{AC}): 0.421 ; \mathrm{R}^{2}(\mathrm{AR}): 0.115 ; \mathrm{R}^{2}(\mathrm{PN}): 0.418 ; \mathrm{R}^{2}(\mathrm{IC}): 0.265 ; \mathrm{R}^{2}(\mathrm{IPM}): 0.363$.

$\mathrm{R}^{2}$ values - Chile: $\mathrm{R}^{2}(\mathrm{NEP}): 0.163 ; \mathrm{R}^{2}(\mathrm{AC}): 0.364 ; \mathrm{R}^{2}(\mathrm{AR}): 0.046 ; \mathrm{R}^{2}(\mathrm{PN}): 0.363 ; \mathrm{R}^{2}(\mathrm{IC}): 0.243 ; \mathrm{R}^{2}(\mathrm{IPM}): 0.332$

$\mathrm{R}^{2}$ values - Spain: $\mathrm{R}^{2}(\mathrm{NEP}): 0.434 ; \mathrm{R}^{2}(\mathrm{AC}): 0.473 ; \mathrm{R}^{2}(\mathrm{AR}): 0.166 ; \mathrm{R}^{2}(\mathrm{PN}): 0.485 ; \mathrm{R}^{2}(\mathrm{IC}): 0.263 ; \mathrm{R}^{2}(\mathrm{IPM}): 0.410$.

As is well known, ecotourism is characterized by being more expensive than other kinds of tourism. However, we have demonstrated that ecotourists are willing to pay more for practicing ecotourism, and this intention to pay more has a high impact on personal norms.

Using the data from our study, companies and institutions working in sustainable tourism can attempt to influence tourists' values (especially biospheric values), beliefs, and attitudes and their intention to undertake ecotourism, thereby improving the marketing and branding of ecotourism products. In this regard, it is necessary to design ecotourism products that provide tourists with a wide range of services on their trips.

Considering that constructs of conscience in consequences and personal norms are the most powerful constructs of the proposed model, ecotourism operators may encourage these attitudes among tourists to enhance their intention to practice ecotourism. They can do this, in particular, by promoting attitudes in favor of sustainable tourism over time through explanatory proposals for environmental education in each of the activities to be carried out, for example, the consumption of $\mathrm{CO} 2$ in airplane travelcarbon footprint, local materials used in construction projects, the rational use of energy, and the production of waste, native plants used in the development of gardens, the consumption of local ecological products, decisions on the daily cleaning of hotel accommodation (towel replacement, etc.), visit to local artisans or farmers, or activities in nature). Similarly, operators should discourage the materialistic behavior of tourists in their establishments in order to promote the consumption of ecological tourism in the future, framing these activities in the strategic plan of the company to influence the decision making of tourists.

People who operate ecotourism businesses must pay attention to the environment, fauna and flora, physical spaces, and communities where they develop their ecotourism activities, combining measures that involve promoting education and environmental behavior with activities such as saving water and energy without undermining the quality of activities, catering, and accommodation. Approaches such as environmental education activities at the family level, informational panels on the ecological footprint of transport, and posters on the previous and current use of water and energy may be used. Information about and traceable origin of organic products consumed in establishments or a relationship with the inhabitants of local communities through cultural or educational activities are of interest in this area.

Therefore, an ecotourism company must enhance its environmental reputation through different strategic plans that combine ecotourists' ecological concerns, business sustainability, and ecological reputation. Ecotourism operators need to invest more resources in increasing ecotourists' awareness of environmental problems and in reflecting this concern in companies' green initiatives.

Likewise, advertising campaigns that provide and disseminate information about ecotourism are needed in the countries studied: Chile and Spain. These campaigns should emphasize how ecotourism drives local economies, protects nature, and improves expectations regarding sustainable development among future generations. Thus, it is important to make a special effort in population sectors that are less inclined to undertake ecotourism or ecological tourism and in sectors that have weaker social and environmental values but show a willingness to undertake naturebased tourism and behave ecologically.

To this end, ecotourism operators could also make their ecological efforts known by disseminating proenvironmental management through their channels of communication with consumers (web, social media, brochures, video, audio, etc.).

With regard to prices, ecotourism operators can set certain price increases for the activities in the appropriate percentage range (below 10\%, according to Laroche et al. 2001) that makes the increase more acceptable to the majority of potential ecotourism 
consumers. These higher prices must necessarily be justified to tourists transparently and credibly in a manner that avoids the idea that the additional expense is a form of ecological attraction or, worse, a useless cost or an expenditure with no return.

The experience of people who practice ecotourism is vitally important because it facilitates changes in their values, attitudes and behaviors, and gaining an understanding of this process is imperative (Walker and Moscardo 2014). In addition, ecotourism operators, through various activities before, during, and after a trip, can improve the experiences of ecotourists so that they have a truly impactful experience that influences their vision of the importance of the environment. Operators can also implement experiences through tourist packages that contribute to the environment (Force et al. 2018). Particularly interesting is research on postvisit activities that facilitate the lived learning experiences, enabling the transformation of environmental attitudes and behaviors to extend over time (Ballantyne and Packer 2011).

Regarding the design of public policies for tourism, these should focus on content that reinforces the idea that tourists' ecological behavior reduces the negative impacts of tourism activities on community environments, the rural world, natural areas, and society. These practices can benefit and help environments that support ecotourism by more effectively conserving, maintaining, and protecting their biological diversity.

\section{LIMITATIONS AND FUTURE AREAS OF RESEARCH}

Beyond the empirical contributions of this study, some limitations have been noted that could offer opportunities for future research in the field of tourism. This study enabled a better understanding of the factors that affect the intention to undertake ecotourism and to pay more for this activity. However, because we used only one TPB construct (Choi et al. 2015), using other constructs could be very interesting. Similarly, we focus on understanding the intention of undertaking ecotourism or paying more for it but do not analyze specific ecotourism behaviors (hotels, visits, activities) and do not apply other instruments that could measure ecotourist behavior in the future.

Owing to the importance of rules in this model, we have focused on understanding the importance of personal and subjective rules, which may present an opportunity to deepen the investigation of the role of rules, following Smith and Louis's (2008) idea of the rules-centered approach. Specifically, it may be of interest to delve more deeply into the classification of descriptive and injunctive norms proposed by Cialdini et al. (1991) in order to gain a better understanding of what people think and do as well as their perception of what behaviors a society approves or does not approve of.

In addition, other aspects that have been studied previously in the literature could be included to understand the antecedents of ecotourism behavior in more detail. For example, it could be very interesting to analyze how the use of informative labels and educational materials influences the ecotourism experience.

Furthermore, because this study is cross-sectional, it would be beneficial to apply it to longer term or longitudinal research. Finally, this cross-cultural study is of two countries that, although on different continents, both have roots in Latin culture. Therefore, it would be interesting to conduct studies on the influence of culture between countries with dissimilar cultures, such as African or Asian countries.

Responses to this article can be read online at: http://www.ecologyandsociety.org/issues/responses. php/11343

\section{LITERATURE CITED}

Aguilar, M. 2006. Predicción de la conducta de reciclaje a partir de la Teoría de la conducta planificada y desde el modelo del valor, normas y creencias hacia el medio ambiente. Thesis, University of Granada, Granada.

Ajzen, I. 1991. The theory of planned behavior. Organizational Behavior and Human Decision Processes 50(2):179-211. https:// doi.org/10.1016/0749-5978(91)90020-T

Anderson, J. C., and D. W. Gerbing. 1988. Structural equation modeling in practice: a review and recommended two-step approach. Psychological Bulletin 103:411-423. https://doi. org/10.1037/0033-2909.103.3.411

Bagozzi, R. P., and Y. Youjae. 1988. On the evaluation of structural equation models. Journal of the Academy of Marketing Science 16:74-94. https://doi.org/10.1007/BF02723327

Ballantyne, R., and J. Packer. 2011. Using tourism free-choice learning experiences to promote environmentally sustainable behaviour: the role of post-visit 'action resources.' Environmental Education Research 17(2):201-215. https://doi.org/10.1080/1350$\underline{4622.2010 .530645}$

Bamberg, S., M. Hunecke, and A. Blöbaum. 2007. Social context, personal norms and the use of public transportation: two field studies. Journal of Environmental Psychology 27(3):190-203. https://doi.org/10.1016/j.jenvp.2007.04.001

Bamberg, S., and G. Möser. 2007. Twenty years after Hines, Hungerford, and Tomera: a new meta-analysis of psycho-social determinants of pro-environmental behaviour. Journal of Environmental Psychology 27(1):14-25. https://doi.org/10.1016/j. jenvp.2006.12.002

Baron, R. M., and D. A. Kenny. 1986. The moderator-mediator variable distinction in social psychological research: conceptual, strategic, and statistical considerations. Journal of Personality and Social Psychology 51(6):1173-1182. https://doi. org/10.1037/0022-3514.51.6.1173

Cepeda, C. G., and S. J. L. Roldán. 2004. Aplicando la técnica PLS en la administración de empresas. Conocimiento y competitividad. Congreso ACEDE 14:74-78.

Chen, M.-F. 2015. An examination of the value-belief-norm theory model in predicting pro-environmental behaviour in Taiwan. Asian Journal of Social Psychology 18:145-151. https:// doi.org/10.1111/ajsp.12096

Chin, W. W. 1998. The partial least squares approach for structural equation modeling. Pages 295-336 in G. A. Marcoulides, editor. Modern methods for business research. Lawrence Erlbaum, Mahwah, New Jersey, USA. 
Choi, H., J. Jang, and J. Kandampully. 2015. Application of the extended VBN theory to understand consumers' decisions about green hotels. International Journal of Hospitality Management 51:87-95. https://doi.org/10.1016/j.ijhm.2015.08.004

Cialdini, R. B., C. A. Kallgren, and R. R. Reno. 1991. A focus theory of normative conduct: a theoretical refinement and reevaluation of the role of norms in human behavior. Advances in Experimental Social Psychology 24:201-234. https://doi. org/10.1016/S0065-2601(08)60330-5

Cox, M., G. Arnold, and S. Villamayor Tomás. 2010. A review of design principles for community-based natural resource management. Ecology and Society 15(4):38. https://doi. org/10.5751/ES-03704-150438

Cué, C. E. 2017. Chile recibe la mayor donación de tierras privadas para parques naturales del planeta. El País, 17 March. [online] URL: http://internacional.elpais.com/internacional/2017/03/16/ actualidad/1489630315 709386.html

Das, M., and B. Chatterjee. 2015. Ecotourism: a panacea or a predicament? Tourism Management Perspectives 14:3-16. https:// doi.org/10.1016/j.tmp.2015.01.002

de Groot, J. I. M., and L. Steg. 2008. Value orientations to explain beliefs related to environmental significant behavior: how to measure egoistic, altruistic, and biospheric value orientations. Environment and Behavior 40:330-354. https://doi. org/10.1177/0013916506297831

Dias, R. 2007. Marketing Ambiental: Ética. Responsabilidade Social e Competitividade nos Negócios. Editora Atlas, São Paulo, Brazil.

Dietz, T., P. C. Stern, and G. A. Guagnano. 1998. Social structural and social psychological bases of environmental concern. Environment and Behavior 30:450-471. https://doi. org/10.1177/001391659803000402

do Paço, A., H. Alves, C. Shiel, and W. L. Filho. 2014. An analysis of the measurement of the construct "buying behaviour" in green marketing. Journal of Integrative Environmental Sciences 11:55-69. https://doi.org/10.1080/1943815X.2014.894082

do Paço, A., and M. Raposo. 2009. "Green” segmentation: an application to the Portuguese consumer market. Marketing Intelligence and Planning 27:364-379. https://doi. org/10.1108/02634500910955245

Dunlap, R. E., and K. D. Van Liere. 1978. The "new environmental paradigm." Journal of Environmental Education 9 (4):10-19.

Dunlap, R. E., K. D. Van Liere, A. G. Mertig, and R. E. Jones. 2000. New trends in measuring environmental attitudes: measuring endorsement of the new ecological paradigm: a revised NEP scale. Journal of Social Issues 56(3):425-442. https://doi. org/10.1111/0022-4537.00176

Epler Wood, M. 2002. Ecotourism: principles, practices \& policies for sustainability. United Nations Environment Programme, Division of Technology, Industry and Economics, Paris, France.

EUROPARC. 2016. EUROPARC-España: Anuario 2016 del estado de las áreas protegidas en España. EUROPARC-España,
Madrid, Spain. [online] URL: http://www.redeuroparc.org/ system/files/shared/Publicaciones/Anuario 2016/anuario_2016 europarcespana.pdf

Falk, R. F., and N. B. Miller. 1992. A primer for soft modeling. University of Akron Press, Akron, Ohio, USA.

Force, A., D. Manuel-Navarrete, and K. Benessaiah. 2018. Tourism and transitions toward sustainability: developing tourists' pro-sustainability agency. Sustainability Science 13:431-445. https://doi.org/10.1007/s11625-017-0448-y

Fornell, C., and D. F. Larcker. 1981. Evaluating structural equation models with unobservable variables and measurement error. Journal of Marketing Research 18(1):39-50. https://doi. org/10.1177/002224378101800104

Goh, E., B. Ritchie, and J. Wang. 2017. Non-compliance in national parks: an extension of the theory of planned behaviour model with pro-environmental values. Tourism Management 59:123-127. https://doi.org/10.1016/j.tourman.2016.07.004

Hair, J. F., M. Sarstedt, L. Hopkins, and V. G. Kuppelwieser. 2014. Partial least squares structural equation modeling (PLS-SEM): an emerging tool in business research. European Business Review 26(2):106-121. https://doi.org/10.1108/ebr-10-2013-0128

Han, H. 2015. Travelers' pro-environmental behavior in a green lodging context: converging value-belief-norm theory and the theory of planned behavior. Tourism Management 47:164-177. https://doi.org/10.1016/j.tourman.2014.09.014

Han, H., J. Hwang, and M. J. Lee. 2017. The value-belief-emotionnorm model: investigating customers' eco-friendly behavior. Journal of Travel \& Tourism Marketing 34:590-607. https://doi. org/10.1080/10548408.2016.1208790

Han, H., and S. S. Hyun. 2017. Drivers of customer decision to visit an environmentally responsible museum: merging the theory of planned behavior and norm activation theory. Journal of Travel \& Tourism Marketing 34:1155-1168. https://doi.org/10.1080/10548408.2017.1304317

Hofstede Insights. 2018. Compare countries. Hofstede Insights, Helsinki, Finland. [online] URL: https://www.hofstede-insights. com/product/compare-countries/

Hultman, M., A. Kazeminia, and V. Ghasemi. 2015. Intention to visit and willingness to pay premium for ecotourism: the impact of attitude, materialism, and motivation. Journal of Business Research 68(9):1854-1861. https://doi.org/10.1016/j.jbusres.2015.01.013

Hwang, K., and J. Lee. 2018. Antecedents and consequences of ecotourism behavior: independent and interdependent selfconstruals, ecological belief, willingness to pay for ecotourism services and satisfaction with life. Sustainability 10(3):789. https:// doi.org/10.3390/su10030789

Ibáñez, R., and I. Rodríguez. 2012. Tipologías y antecedentes de la actividad turística: turismo tradicional y turismo alternativo. Medio ambiente y política turística en México 1:17-33.

Ibtissem, M. H. 2010. Application of value beliefs norms theory to the energy conservation behaviour. Journal of Sustainable Development 3:129-139. https://doi.org/10.5539/jsd.v3n2p129 
Instituto Nacional de Estadística (INE). 2016. Encuesta de movimientos turisticos de los Españoles Familitur (2016). INE, Madrid, Spain. [online] URL: https://www.ine.es/CDINEbase/ consultar.do? mes $=$ \&operacion $=$ Encuesta + de + Turismo + de + $\underline{\text { Residentes\&id oper }=\mathrm{Ir}}$

Jansson, J., A. Marell, and A. Nordlund. 2010. Green consumer behavior: determinants of curtailment and eco-innovation adoption. Journal of Consumer Marketing 27(4):358-370. https:// doi.org/10.1108/07363761011052396

Jöreskog, K. G., and H. Wold. 1982. The ML and PLS techniques for modeling with latent variables: historical and comparative aspects. Pages 263-270 in K. G. Jöreskog and H. Wold, editors. Systems under indirect observation Vol. I. North-Holland, Amsterdam, The Netherlands.

Juric, B., T. B. Cornwell, and D. Mather. 2002. Exploring the usefulness of an ecotourism interest scale. Journal of Travel Research 40:259-269. https://doi.org/10.1177/0047287502040003004

Kaiser, F. G., G. Hübner, and F. X. Bogner. 2005. Contrasting the theory of planned behavior with the value-belief-norm model in explaining conservation behavior. Journal of Applied Social Psychology 35:2150-2170. https://doi.org/10.1111/j.1559-1816.2005. tb02213.x

Kiatkawsin, K., and H. Han. 2017. Young travelers' intention to behave pro-environmentally: merging the value-belief-norm theory and the expectancy theory. Tourism Management 59:76-88. https://doi.org/10.1016/j.tourman.2016.06.018

Kvasova, O. 2015. The big five personality traits as antecedents of eco-friendly tourist behavior. Personality and Individual Differences 83:111-116. https://doi.org/10.1016/j.paid.2015.04.011

Landon, A. C., K. M. Woosnam, and B. B. Boley. 2018. Modeling the psychological antecedents to tourists' pro-sustainable behaviors: an application of the value-belief-norm model. Journal of Sustainable Tourism 26(6):957-972. https://doi. org/10.1080/09669582.2017.1423320

Laroche, M., J. Bergeron, and G. Barbaro-Forleo. 2001. Targeting consumers who are willing to pay more for environmentally friendly products. Journal of Consumer Marketing 18:503-520. https://doi.org/10.1108/EUM0000000006155

Lee, T. H., and F.-H. Jan. 2018. Ecotourism behavior of naturebased tourists: an integrative framework. Journal of Travel Research 57:792-810. https://doi.org/10.1177/0047287517717350

Liu, X., Y. Zou, and J. Wu. 2018. Factors influencing publicsphere pro-environmental behavior among Mongolian college students: a test of value-belief-norm theory. Sustainability 10 (5):1384. https://doi.org/10.3390/su10051384

López-Mosquera, N. 2016. Gender differences, theory of planned behavior and willingness to pay. Journal of Environmental Psychology 45:165-175. https://doi.org/10.1016/j.jenvp.2016.01.006

López-Mosquera, N., and M. Sánchez. 2011. The influence of personal values in the economic-use valuation of peri-urban green spaces: an application of the means-end chain theory. Tourism Management 32(4):875-889. https://doi.org/10.1016/j. tourman.2010.08.003
Lu, A. C. C., D. Gursoy, and G. Del Chiappa. 2016. The influence of materialism on ecotourism attitudes and behaviors. Journal of Travel Research 55:176-189. https://doi.org/10.1177/0047287514541005

Manrai, L. A., and A. Manrai. 2011. Hofstede's cultural dimensions and tourist behaviors: a review and conceptual framework. Journal of Economics, Finance \& Administrative Science 16:23-48.

Martone, R. G., A. Bodini, and F. Micheli. 2017. Identifying potential consequences of natural perturbations and management decisions on a coastal fishery social-ecological system using qualitative loop analysis. Ecology and Society 22 (1):34. https://doi.org/10.5751/ES-08825-220134

McGinnis, M., and E. Ostrom. 2014. Social-ecological system framework: initial changes and continuing challenges. Ecology and Society 19(2):30. https://doi.org/10.5751/ES-06387-190230

Meng, F. 2010. Individualism/collectivism and group travel behavior: a cross-cultural perspective. International Journal of Culture, Tourism and Hospitality Research 4(4):340-351. https:// doi.org/10.1108/17506181011081514

Miguens, M. J. L., P. Á. González, and E. G. Vázquez. 2015. Conocimiento, valores e intenciones como determinantes del comportamiento ecológico. Revista Internacional de Sociología 73:e018. https://doi.org/10.3989/ris.2015.73.3.e018

Ministerio de Agricultura, Pesca y Alimentación (MAPAM). 2017. El turismo de naturaleza en España. MAPAM, Madrid, Spain. [online] URL: https://www.mapa.gob.es/es/ministerio/ servicios/analisis-y-prospectiva/seriemedioambienten9 turismodenaturalezaenespana tcm30-419763.pdf

Nel-lo, M., and C. Llanes. 2016. Ecoturismo. Universitat Oberta de Catalunya, Barcelona, Spain.

Nordlund, A. M., and J. Garvill. 2003. Effects of values, problem awareness, and personal norm on willingness to reduce personal car use. Journal of Environmental Psychology 23:339-347. https:// doi.org/10.1016/S0272-4944(03)00037-9

Notiamérica. 2015. Chile apuesta por el turismo de naturaleza para contribuir al desarrollo de las zonas rurales. Notiamérica, 02 February. [online] URL: https://www.notimerica.com/economia/ noticia-chile-apuesta-turismo-naturaleza-contribuir-desarrollo-zonasrurales-20150131135934.html

Nunnally, J. C. 1978. Psychometric theory. McGraw-Hill, New York, New York, USA.

Puhakka, R., and P. Siikamäki. 2012. Nature tourists' response to ecolabels in Oulanka PAN Park, Finland. Journal of Ecotourism 11:56-73. https://doi.org/10.1080/14724049.2011.647917

Pulido-Fernández, J. I., and Y. López-Sánchez. 2016. La cadena de valor del destino como herramienta innovadora para el análisis de la sostenibilidad de las políticas turísticas. El caso de España. Innovar 26:155-176. https://doi.org/10.15446/innovar.v26n59.54369

Ringle, C. M., S. Wende, and A. Will. 2017. SmartPLS 2.0 (beta). [online] URL: http://www.smartpls.de

Sarstedt, M., C. M. Ringle, D. Smith, R. Reams, and J. F. Hair. 2014. Partial least squares structural equation modeling (PLSSEM): a useful tool for family business researchers. Journal of 
Family Business Strategy 5:105-115. https://doi.org/10.1016/j. jfbs.2014.01.002

Schwartz, S. H. 1977. Normative influences on altruism. Advances in Experimental Social Psychology 10:221-279. https://doi. org/10.1016/S0065-2601(08)60358-5

Schwartz, S. H. 1992. Universals in the content and structure of values: theoretical advances and empirical tests in 20 countries. Advances in Experimental Social Psychology 25:1-65. https://doi. org/10.1016/S0065-2601(08)60281-6

Schwartz, S. H., and W. Bilsky. 1987. Toward a universal psychological structure of human values. Journal of Personality and Social Psychology 53:550-562. https://doi.org/10.1037/0022$\underline{-3514.53 .3 .550}$

Schwartz, S. H., and J. A. Howard. 1981. A normative decisionmaking model of altruism. Pages 189-211 in J. P. Rushton and R. M. Sorrentino, editors. Altruism and helping behavior. L. Erlbaum Associates, New York, New York, USA.

SENATUR. 2013. Medición y comportamiento del Turismo Interno 2012. SENATUR, Santiago, Chile. [online] URL: $\underline{\text { http:// }}$ www.subturismo.gob.cl/wp-content/uploads/2015/11/Medición-yComportamiento-del-Turismo-Interno-Año-2012.pdf

SENATUR. 2015. Anuario de turismo 2014 Chile. SENATUR, Santiago, Chile. [online] URL: http://www.subturismo.gob.cl/wpcontent/uploads/2015/11/Anuario-2014.pdf

SENATUR. 2017. Anuario de turismo. SENATUR, Santiago, Chile. [online] URL: http://www.subturismo.gob.cl/wp-content/ uploads/2015/10/ANUARIO-TURISMO-2017.pdf

Smith, J. R., and W. R. Louis. 2008. Do as we say and as we do: the interplay of descriptive and injunctive group norms in the attitude-behaviour relationship. British Journal of Social Psychology 47(4):647-666. https://doi.org/10.1348/014466607X269748

Steg, L., L. Dreijerink, and W. Abrahamse. 2005. Factors influencing the acceptability of energy policies: a test of VBN theory. Journal of Environmental Psychology 25(4):415-425. https://doi.org/10.1016/j.jenvp.2005.08.003

Stern, P. C. 1999. Information, incentives, and proenvironmental consumer behavior. Journal of Consumer Policy 22(4):461-478. https://doi.org/10.1023/A:1006211709570

Stern, P. C. 2000. New environmental theories: toward a coherent theory of environmentally significant behavior. Journal of Social Issues 56(3):407-424. https://doi.org/10.1111/0022-4537.00175

Stern, P. C., T. Dietz, T. Abel, G. A. Guagnano, and L. Kalof. 1999. A value-belief-norm theory of support for social movements: the case of environmentalism. Human Ecology Review 6:81-97.

Stern, P. C., L. Kalof, T. Dietz, and G. A. Guagnano. 1995. Values, beliefs, and proenvironmental action: attitude formation toward emergent attitude objects. Journal of Applied Social Psychology 25:1611-1636. https://doi.org/10.1111/j.1559-1816.1995.tb02636. $\underline{\mathrm{X}}$

Untaru, E. N., G. Epuran, and A. Ispas. 2014. A conceptual framework of consumers' pro-environmental attitudes and behaviours in the tourism context. Bulletin of the Transilvania University of Braşov Series V: Economic Sciences 7:85-94.

Van Liere, K. D., and R. E. Dunlap. 1978. Moral norms and environmental behavior: an application of Schwartz's normactivation model to yard burning. Journal of Applied Social Psychology 8:174-188. https://doi.org/10.1111/j.1559-1816.1978. tb00775.x

van Riper, C. J., and G. T. Kyle. 2014. Understanding the internal processes of behavioral engagement in a national park: a latent variable path analysis of the value-belief-norm theory. Journal of Environmental Psychology 38:288-297. https://doi.org/10.1016/j. jenvp.2014.03.002

Walker, K., and G. Moscardo. 2014. Encouraging sustainability beyond the tourist experience: ecotourism, interpretation and values. Journal of Sustainable Tourism 22(8):1175-1196. https:// doi.org/10.1080/09669582.2014.918134

Weaver, D. B., and L. J. Lawton. 2002. Overnight ecotourist market segmentation in the Gold Coast hinterland of Australia. Journal of Travel Research 40(3):270-280. https://doi. org/10.1177/004728750204000305

Weaver, D. B., and L. J. Lawton. 2007. Twenty years on: the state of contemporary ecotourism research. Tourism management 28 (5):1168-1179. https://doi.org/10.1016/j.tourman.2007.03.004

World Tourism Organization. 2019. UNWTO World Tourism Barometer and Statistical Annex, January 2019. World Tourism Organization, Madrid, Spain. [online] URL: https://www.eunwto.org/doi/abs/10.18111/wtobarometereng.2019.17.1.1

Wynveen, C. J., B. J. Wynveen, and S. G. Sutton. 2015. Applying the value-belief-norm theory to marine contexts: implications for encouraging pro-environmental behavior. Coastal Management 43:84-103. https://doi.org/10.1080/08920753.2014.989149

Yeboah, F. K., and M. D. Kaplowitz. 2016. Explaining energy conservation and environmental citizenship behaviors using the value-belief-norm framework. Human Ecology Review 22 (2):137-160 https://doi.org/10.22459/her.22.02.2016.06 